\title{
And the winners are ... The official results of the 2007 ACRL elections
}

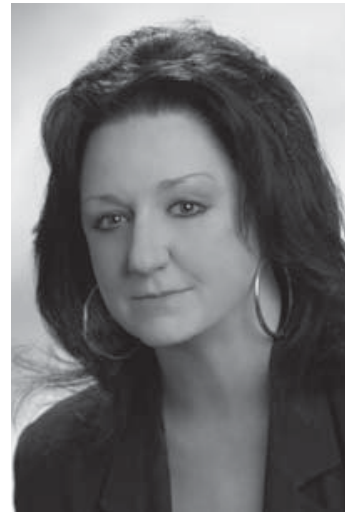

Julie Todaro

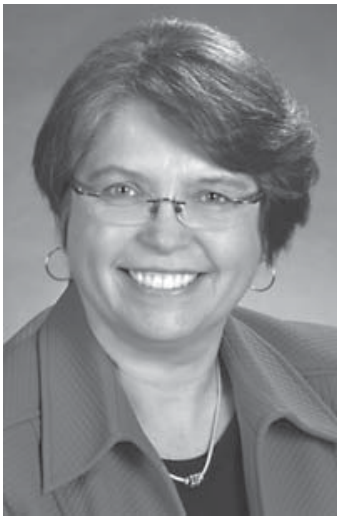

Erika Linke
Julie Todaro, dean of library services at Austin Community College, is the 70th president of ACRL.

"My original or 'campaign' vision for ACRL included the need for association flexibility; a focus on competitive, diverse delivery and content for continuing education; continued emphasis on significant partnerships with other organizations and associations; and significant expansion of our marketing of the association and the profession in general. I am excited about the opportunity (and we are already working!) to focus on ideas from ACRL's strategic plan that will best illustrate my overall goals and especially my initiative to assess and expand use of ACRL's recruitment and marketing materials.

"In addition, I am committed to identifying retention strategies for our newest professionals-not only for workplace retention, but retention in ACRL and in the profession in general. 'Watch this space' for President's columns that combine theory with practice; a President's program in Anaheim; an extensive recruitment and retention wiki with pathfinders and best practices; and recommendations for using ACRL marketing materials."
As president, Todaro will preside over the ACRL Board of Directors and ACRL Executive Committee, chair the ACRL Conference Program Planning Committee for the 2008 Annual Conference, and plan ACRL's major program at the conference. She will work with the ALA president and other division presidents representing ACRL both within and outside of ALA.

From 1984 to 2001, Todaro was head librarian at the Austin Community College Rio Grande Campus. Todaro also served as assistant professor at the University of Michigan's School of Information (1980-84).

Her activities in ACRL include serving on the Grassroots Library Advocacy Presidential Task Force (2004-06), as a member of the CERL News Editorial Board (2002-06), and as chair of the Council of Liaisons (2003-06), of which she was also a member (1988-90, 2000-03). Todaro served as cochair of the 2005 National Conference Invited Papers Subcommittee (2003-05), and as cochair of the Institute for Information Literacy (1997-99).

Todaro's work with state and regional associations has included membership in the Texas Library Association (TLA), with service as chair of the Legislative Committee (2003-05), chair of the College and University Library Division (1992-94), member of the Tall Texans Leadership Committee on Implementation (1992-94), and chair of the President's Committee on Committees (2004). She also served a term as president of TLA, (2000-01).

She has been involved with the American Association of Community Colleges as a commission member (2001-05), and was a Board member for Connections: A Resource Center 
for Childcare Providers and Parents (19942004), during which time she also served a term as president. Todaro was an advisory commission member of the Austin Public Library (1992-97), and served on the Texas State Library and Archives Committee as a Library Services and Technology Act Advisory Board member (1989-92). She is also involved with the Texas Book Festival Advisory Board (1996-present).

Todaro was selected as one of the "2005 Profiles in Power" by the Austin Business Journal (2005), and was awarded a LAMA Certificate of Recognition for her work on the "Truth is Out There" Column (2004). The Austin Community College Library Services Information Literacy Program was selected as an ACRL Institute for Information Literacy Best Practice (2002), and the library was awarded the ACRL Excellence in Academic Libraries Award (2001). Todaro was awarded the YWCA's Austin Educator of the Year Award (1999), and was the Texas Library Association's Librarian of the Year (1996).

Her publications include "The Truth is Out There," LAMA Journal (LAMA), quarterly column (1997-present); "Nothing But Net," Community and Junior College Libraries (Haworth), quarterly column (1996-present); and coauthor of Extraordinary Customer Service (working title)," (Neal-Schuman, 2006).

Todaro received her master's of library science from the University of Texas at Austin, and her Ph.D. from Columbia University's School of Library Service.

Erika Linke, associate dean of university libraries at Carnegie Mellon University, has been elected vice president/president elect of ACRL.

"I am honored to serve as the next vicepresident/president elect of ACRL. I want to thank everyone who voted in this closely contended election. You care about the association's future. We are unified by our identity as academic and research librarians, even if we have slightly different ideas about how to advance our role. Following a close election, it is time to turn attention to the issues articulated by the association members and to set a direction for the future-to advance the goals of the association through member participation. It is the association that is important.

"During the election, ACRL members shared with me their thoughts, ideas, and inspiration. We must keep our gaze on the horizon and the opportunities to achieve goals set forth in the strategic plan. I invite ACRL members to share their ideas with me in person, by phone or by e-mail at el08@andrew.cmu.edu. Dialogue is the cornerstone of a robust committed organization. Let us work together as an association to continue to define priorities, develop solutions, and to forge our future.

"Learning about association and member needs is an ongoing endeavor. Ongoing dialogue with ACRL groups, sections, and members provides context and depth, and a greater appreciation of the ambitions and goals of members. It is a true delight to meet members and hear their stories. The goals and aspirations of the association mean little without member participation. Our national conference is but one example of how the association engages members. I am eager to begin my term of office to focus on the goals in the strategic plan and especially those areas of most concern to me-scholarly communication, advocacy, and new members. With your help, we can ensure that ACRL is the vibrant organization that we need and want."

From 1984 to 2005, Linke held numerous positions at Carnegie Mellon University including associate dean of university libraries for collection and user services (2003-05), associate university librarian for collection and user services (2001-03), associate university librarian for access services (1998-2001), acting university librarian (1996-98), assistant university librarian for access services (1993-98), head of collections and access (1991-93), head of acquisitions and collection development (1985-91), and conversion specialist and reference librarian (1984-85). She also served as head of interlibrary loan and INFORM at the University of Minnesota (1982-83).

Her activities in ACRL include serving as chair of the Excellence in Academic Librar- 
ies Nominations Committee (2006-07), as a member of the Scholarly Communication Committee (2005-07), and as cochair of the 2007 National Conference Contributed Papers Committee (2005-07). Linke also served as chair of the Budget and Finance Committee (2001-03), and on the ACRL Board of Directors (2001-03). She was chair of the Copyright Committee (1995-97), and has been a member of ALCTS, LAMA, LITA, and RUSA since 1985.

Linke's work with state and regional associations has included membership in the Western Pennsylvania/West Virginia Chapter of ACRL (WPWVC), with service as chapter president (2003-04), as a member of the Board of Directors (2001-04), and as a member of the WPWVC Revitalization Committee (2000-01). She also served on the Oakland Library Consortium's Board of Directors (1996-98).

Linke currently serves on the PALINET Board of Trustees (2005-present). She has been a member of the Southwestern Pennsylvania Program for Deliberative Democracy Advisory Board since 2006, and has been a Pittsburgh Bibliophiles Advisory Board member since 2001. Linke has been involved with the North American Serials Interest Group (1986-present) and affiliated with the Association for Asian Studies (1980-present).

Linke was a UCLA Senior Fellow in 2003.

Her publications include coauthor of "Changing the Publishing Paradigm for Science and Technology," Science \& Technology Libraries, v.24 (no. 1/2) 2003; coauthor of "Scholarly Use of Information: Graduate Students' Information-Seeking Behavior," Information Research, v. 11 (no. 4) July 2006; and "Addressing Staff Concerns in Changing Times: Supporting the Institution's Greatest Asset," IATUL Proceedings, n.s. 14, 2004.

Linke received her master's of library science from the University of Minnesota, and her bachelor of arts degree in German and Chinese from Miami University (Ohio).

\section{ACRL}

Vice-President/President-Elect: Erika C. Linke (1645), elected by lot; Scott Walter (1645).

\section{ACRL Board}

Director-at-Large (4-year term): Trevor A. Dawes (1408); Michael John LaCroix (1562).

Director-at-Large (4-year term): Elizabeth A. Dupuis (2093); R. N. Sharma (920).

Councilor (3-year term): Albie Johnson (1121); Locke J. Morrisey (1810).

\section{African American Studies Librarians Section (AFAS)}

Vice-chair/Chair-elect: Thomas Weissinger (70); Write-in candidate (3).

Secretary: Sylvia A. Nyana (41); Bonnie Crarey Ryan (31).

Member-at-Large (2-year term): Gennice W. King (33); Allison Sutton (40).

\section{Anthropology and Sociology Section (ANSS)}

Vice-chair/Chair-elect: Pauline D. Manaka (54); Randy Hertzler (68).

Secretary: Jennifer Nason Davis (109); Write-in candidate $(0)$.

Member-at-Large (2-year term): Terrence Epperson (105); Write-in candidate (2).

\section{Arts Section}

Vice-chair/Chair-elect: Lucie Wall Stylianopoulos (157); Write-in candidate (3).

Secretary (1-year term): Sara Harrington (161); Write-in candidate (0).

\section{Asian, African, and Middle Eastern Section (AAMES)}

Vice-chair/Chair-elect: Rajwant S. Chilana (69); Write-in candidate (0).

Secretary: Doris Jean Seely (67); Write-in candidate (0).

Member-at-Large (2-year term): Michael Meng (68); Write-in candidate (0).

\section{College Libraries Section (CLS)}

Vice-chair/Chair-elect: William N. Nelson (295); Irene M. H. Herold (412).

Secretary: Michael J. Miller (220); Kristin D. Vogel (466).

Member-at-Large (2-year term): Eric A. Kidwell (259); Celia Rabinowitz (421). 


\section{Community and Junior College Libraries Section (CJCLS)}

Vice-chair/Chair-elect: Lora P. Mirza (287); Write-in candidate (2).

Secretary: Ann Coder (288); Write-in candidate (3).

\section{Distance Learning Section (DLS)}

Vice-chair/Chair-elect: Patrick B. Mahoney (211); David L. Bickford (178).

Secretary/Archivist: Sandra Lee Hawes (134); Sarah Jane Hammill (250).

Member-at-Large (2-year term): Stephan J. Macaluso (192); Ann Campion Riley (194).

\section{Education and Behavioral Sciences Section (EBSS)}

Vice-chair/Chair-elect: Venta E. Silins (115); Deborah L. Schaeffer (127).

Secretary: Vanessa J. Earp (214); Write-in candidate (4).

Member-at-Large (2-year term): Ann E. Brownson (143); Adrian K. Ho (90).

\section{Instruction Section (IS)}

Vice-chair/Chair-elect: Susan Miller (447); Sarah McDaniel (630).

Secretary: Susan A. Vega Garcia (1002); Writein candidate (11).

Member-at-Large (3-year term): Christopher Hollister (514); Ellysa Stern Cahoy (529).

\section{Law and Political Science Section (LPSS)}

Vice-chair/Chair-elect: Ann Marshall (92); Dennis K. Lambert (34).

Secretary: Mary M. Gilles (121); Write-in candidate (1).

Member-at-Large (2-year term): Brian E. Coutts (62); Evan James Rusch (57).

\section{Literatures in English Section (LES)}

Chair (special election): Sophie Lesinska (126); Write-in candidate (1).

Vice-chair/Chair-elect: Karen Elizabeth Munro (67); Elected by lot: Angela Courtney (67).

Secretary: Meg Meiman (78); John Novak (50). Member-at-Large (1-year term): Juliet Kerico (61); Sara Seten Berghausen (70).

\section{Rare Books and Manuscripts Section (RBMS)}

Vice-chair/Chair-elect: Steven Escar Smith (139); Mary A. Lacy (249).

Secretary: Erika Dowell (108); Beth M. Russell Whittaker (262).

Member-at-Large (3-year term): Ronald D. Patkus (104); Melissa Conway (271).

\section{Science and Technology Section (STS)}

Vice-chair/Chair-elect: Philip Herold (152); Virginia Ann Baldwin (209).

Secretary: Rocco M. Piccinino (143); Lori Jean Ostapowicz Critz (206).

\section{Slavic and East European Section (SEES)}

Chair (special election): George Andrew Spencer (51); Write-in candidate (0).

Vice-chair/Chair-elect: Terri Miller (49); Writein candidate $(0)$.

Secretary: Jon Giullian (20); Jackie Byrd (29)

\section{University Libraries Section (ULS)}

Vice-chair/Chair-elect: Barbara Baxter Jenkins (834); Cory Tucker (453).

Secretary: Glenda A. Thornton (693); Betsy Baker (602).

Member-at-Large (3-year term): Mary Munroe (849); Julianne Patrice Hinz (770); Write-in candidate (12).

\section{Western European Studies Section (WESS)}

Vice-chair/Chair-elect: Fred W. Jenkins (51); Laura Dale Bischof (104).

Secretary: Timothy Shipe (67); Rowena Griem (81).

Member-at-Large (1-year term): Jonathan C. Marner (77); Joy Pile (65).

\section{Women's Studies Section (WSS)}

Vice-chair/Chair-elect: Pamela Mann (57);

Diana L. King (81).

Secretary: Piper Martin (72); Sharon Ladenson (62).

Member-at-Large (2-year term): Jane Nichols (64); Marilyn A. Dunn (70). z 


\section{Inaugural ACRL legislative advocates appointed}

To supplement the existing ACRL Legislative Network,ACRL created the new position of legislative advocate. The Government Relations Committee reviewed applications from ACRL members who are interested in federal legislation and policy affecting libraries and willing to work for change.

All those selected have agreed to take on a set of responsibilities that further ACRL's legislative advocacy goals. These responsibilities include establishing relationships with their Members of Congress and with campus leaders who may be advocates for library issues; making yearly in-person visits to the local offices and, as possible, the Washington offices of their senators and representative; and communicating with senators and representatives in response to at least three action alerts per year on selected issues of importance as identified by ACRL.

Legislative advocates will serve a two-year term, which may be renewed without limit at the option of the advocate and upon review. Congratulations and thank you to:

Rachel Bridgewater, Washington State University Vancouver, OR

Anne Britton, Harvard College Library, MA

Susan Brynteson, University of Delaware Library, DE

Sarah F Cohen, Champlain College, VT

Carrie Cooper, Eastern Kentucky University, KY

Sean Cordes, Iowa State University, IA

Joe Dahlstrom, University of Houston-

Victoria \& Victoria College,TX

Trisha Davis, The Ohio State University Libraries, $\mathrm{OH}$

Mark de Jong, University of Maryland University College, MD

Ray English, Director of Libraries, Oberlin College, $\mathrm{OH}$

Hector Escobar, University of Notre Dame, IN

Cristina Favretto, University of California-Los Angeles, CA

Lois Fitzpatrick, Carroll College, MT

Marc Gartler, Harrington College of Design, IL

Ravonne Green, Valdosta State University, GA

Deborah Hagemeier, Augustana College, SD

W. Lee Hisle, Connecticut College, CT

Barbara Jones, Wesleyan University, CT
Charles Kratz, The University of Scranton, PA

Debbie Malone, DeSales University, PA

Jonathan Miller, Rollins College, FL

Lorena O'English, Washington State University, WA

Pattie Piotrowski, Illinois Institute of Technology, IL

Todd Quinn, Dakota State University, SD

Cristina Ramirez, Virginia Commonwealth University, VA

Greg Raschke, NCSU Libraries, NC

Luis Rodriguez, Kean University, NJ

Brena Smith, Westwood College, CA

Aline Soules, California State University,

East Bay, CA

Duncan Stewart, University of Iowa, IA

Julie Todaro, Austin Community College,TX

Doris Van Kampen, Saint Leo University, FL

Jan Wilbur, Associate Assumption College, $\mathrm{ME}$

Larry Wild, Judson College, IL

Catherine Wojewodzki, University of Delaware, DE

Arthuree Wright, Howard University Libraries, MD

Daryl Youngman, Kansas State University, KS 